\title{
Legitimizing Gerrymandering in the Harari Regional State Contrary to the Principle of Equality of Votes
}

\author{
DOI http://dx.doi.org/10.4314/mlr.v15i1.10
}

\author{
Simeneh Kiros Assefa *
}

\begin{abstract}
The National Election Board of Ethiopia (NEBE) had rejected the request to enable ethnic-Hararis who reside outside Harari Regional State to vote in the election of Harari National Council members. The Board stated that it is not bound by prior practices that do not have constitutional foundation. The Board further noted that accepting such demand would jeopardize the fairness and impartiality of the Board against other minority ethnic groups whose members reside outside their national state. NEBE argued that article 50(2) of the Harari Constitution contradicts the provision of article 50(3) of the FDRE Constitution. However, based on the Harari National Council's petition to the Federal Supreme Court, the decision of NEBE has been reversed, and this has been further affirmed by the FSC Cassation Division. This comment examines the legal foundation and propriety of the decisions of the Federal Supreme Court and the FSC Cassation Division. Inter alia, the FSC Cassation Division has misinterpreted a provision under article 50(2) of the Harari Regional State Constitution that expressly refers to the right to be candidate in elections at place of birth as opposed to voting rights irrespective of residence.
\end{abstract}

\section{Key terms}

Equality of votes · Gerrymandering $\cdot$ Preferential treatment $\cdot$ Harari Regional State

\section{Suggested citation:}

Simeneh Kiros Assefa (2021), 'Legitimizing Gerrymandering in the Harari Regional State Contrary to the Principle of Equality of Votes', 15 Mizan Law Review 1: 271296.

- Simeneh Kiros Assefa, PhD, Associate Professor of Law, Addis Ababa University School of Law; Email: simeneh@simenehlaw.com

ORCID: https://orcid.org/0000-0003-0915-9360

Frequently used acronyms

FDRE Federal Democratic Republic of Ethiopia

FSC Federal Supreme Court

NEBE National Election Board of Ethiopia

TGE Transitional Government of Ethiopia, 1991-1995 


\section{Introduction}

When the Hararis claimed statehood in the post-1991 state structure, they were outnumbered by non-Hararis in the city of Harar other than the walled part of the city, i.e., Jugol. The Harari people organised committee of experts who proposed solutions to 'the problem'. The proposal included legally guaranteeing majority for the ethnic-Hararis in the future Harari State Council. This was to be obtained by introducing gerrymandering, and by defining a Harari as "resident" wherever he/she resides and however long he/she may be away from the state, and define the non-Hararis as "settlers".

The proposal was adopted by the Transitional Government of Ethiopia Council of Representatives in its $102^{\text {nd }}$ Regular Session. Accordingly, the Harari People State Council is composed of two chambers - the Harari State Council having 22 members, of which 4 are to be elected from Jugol and 18 are to be elected in urban and rural kebeles outside Jugol including Hunde Wereda. The Harari National Council, having 14 seats, is exclusively elected from ethnic-Harari. Consequently, out of the 36 seats of the State Council, the Harari hold 18. In this manner the previous five rounds of elections were conducted.

In the sixth round of elections, the National Election Board of Ethiopia refused to register Hararis residing outside of the state to vote for members of the state, among others. The Harari National Council appealed to the Federal Supreme Court which quashed the decision of the Board. The Board petitioned the Federal Supreme Court Cassation Division ('FSC Cassation Division') on the ground of fundamental error of law. The FSC Cassation Division $^{1}$ affirmed the decision of the Federal Supreme Court.

\footnotetext{
${ }^{1}$ Cass File No 207036

May 27, 2021

Judges: Birhanu Amennew

Teferi Gebru, PhD

Etmet Assefa

Dejene Ayansa

Birknesh Esubalew

Petitioner: The National Election Board of Ethiopia

Present through its representative - Awudro Tadesse

Respondent: Harari National Council of the Harari People State Council of Representatives

Present through its representative Selhadin Tewfiq
} 
This comment critiques this decision of the FSC Cassation Division. In Section 2 it summarises the case. Sections 3 and 4 are critiques on the judgment based on the principle of universal and equal suffrage, and territorial nature of the right to vote. In order to give context to the discussion, the power of the Harari National Council is also discussed. The critique in Section 5 relates to FSC Cassation Division interpretative method relating to the court's jurisdiction on the interpretation of the Constitution. It also describes constitutional interpretation and argues that there was a need for constitutional interpretation. The critique in Section 6 shows that the FSC Cassation Division has avoided the issues, and has allowed wrong impressions and misrepresentations to stand unaddressed. The comment further discusses the significance of the Minutes of the TGE Council of Representatives by looking at the entirety of the document. Section 7 deals with matters that are not considered and special representation of minorities. Section 8 discusses issues that are worth considering in the future. It includes, ownership of a region, question of identity and public interest in constitutional litigation.

\section{The FSC Cassation Division's Summary of the Case ${ }^{2}$}

\subsection{Overview of the case}

The following four entities: (i) the Harari National Council of the Harari People State Council of Representatives, (ii) Secretariat of the Harari People State Council of Representatives, (iii) Office of the President of the Harari National Regional State, and (iv) Harari Region Prosperity Party submitted a petition to the National Election Board of Ethiopia ('NEBE' or 'the Board') and asked the Board to register ethnic-Hararis residing outside of the regional state to vote for their state and federal representatives in Harari state. In their petition to the NEBE written on different dates, the request stated that Harari nationals residing outside of the Regional State elected their representatives in the previous five rounds of elections and it is done as per the decision of the Council of Representatives of the Transitional Government of Ethiopia made on March 15, 1995 in its $102^{\text {nd }}$ Regular Session.

The NEBE rejected the request on the ground, among others, that as per the FDRE Constitution, citizens that can vote in constituting a national

\footnotetext{
${ }^{2}$ In the normal practice, this section would have been summary of the facts. However, as it is a cassation summary (exclusively meant to address fundamental error of law), it is referred to as summary of the case. This is also because some of the author's comments relate to the Court's summary of the case.
} 
regional council are only residents of such state that are eligible to vote; that there is no preferential treatment solely for this group and there is no constitutional ground. The Board indicated that it is not bound by the prior practices that are not aligned with the Constitution, and the core element of the electoral reform involves setting aside such practices that do not have constitutional foundation. The Board further stated that, should the Board accept such demand, the fairness and impartiality of the Board would be jeopardised among other minority ethnic groups whose members reside outside of their national state.

The Harari National Council of the Harari People Regional State petitioned the Federal Supreme Court to have the decision of the NEBE reversed. The NEBE in its reply before the Federal Supreme Court asserted that the provisions of article 50(2) of the Harari Constitution contradict the provision of article 50(3) of the FDRE Constitution, raising a constitutional dispute which, thus, falls under the jurisdiction of the House of Federation.

Regarding jurisdiction and constitutionality of the regional constitution, the Federal Supreme Court, reproducing both provisions of the FDRE Constitution and the Harari Constitution held that they do not contradict. The Federal Constitution provides for general matters and the Harari Regional State Constitution provides for special matters; such is the case with article 17(3) of the Ethiopian Electoral, Political Parties Registration and Election's Code of Conduct Proclamation No 1162/2019 which requires the Board to organise elections for those who reside outside of the country. Therefore, the Federal Constitution accommodates exceptions, and therefore, there is no contradiction between the two.

Going to the merits of the case, the Federal Supreme Court decided that the prior five rounds of elections were not conducted without a legal justification; they were undertaken as per the decision of the Council of Representatives of the TGE made on March 15, 1995 in its $102^{\text {nd }}$ Regular Session and the Constitution of the Harari Regional State. Further, the Minutes of the $102^{\text {nd }}$ Regular Session of the TGE Council of Representatives were adopted after the coming into force of the FDRE Constitution. In all rounds of those prior elections, there has never been a contrary decision against those documents; if the Board believes those documents were unconstitutional, it could have sought repeal by an organ that has jurisdiction and the Board cannot just decide to reject them.

The cassation petition was filed against this decision of the Federal Supreme Court. The grounds of cassation petition, further include the alleged wrong interpretation of organising election for those who temporarily reside outside of their constituency, as per article 17 of the 
Electoral Proclamation No $1162 / 2019$. The other ground of the petition is that, the power to adopt electoral law is constitutionally granted to the Federal Government; regional states may only define the number of seats for the particular assembly. Thus, the Harari Regional State's Constitution providing for the manner of election is contrary to the FDRE Constitution particularly because voting rights are territorial. The NEBE petition also alleges that the Federal Supreme Court does not address these two arguments.

The respondent (the Harari National Council of the Harari People Regional State Council) replied that as per the provisions of article 17(1) of the National Election Board of Ethiopia Establishment Proclamation No $1133 / 2019$, the final decision of the Board may be reviewed by the Federal Supreme Court. Regarding the matter that is in dispute, the Respondent replied that ethnic-Harari people residing outside of the state may elect both their federal and state representatives as per the decision of Council of Representatives of TGE made on March 15, 1995 in its $102^{\text {nd }}$ Regular Session and the provisions of articles 49 and 50(2) of the Regional State Constitution. According to the Respondent, these provisions are clear that they are not in want of interpretation, and such was the positive decision for the self-governance of the Harari people.

The Respondent further argued that while the Committee of Experts that presented its report to the Council of Representatives of TGE had reviewed and shared the experience of other countries regarding the rights of minority and the contents of international agreements to which Ethiopia is a party, the Board's decision (holding those rules are lacking constitutional foundation) is a fundamental mistake, and merely shows erroneous understanding. (paragraph 9 of the Cassation Court Judgment). The Respondent stated that while the decision of the Council of Representatives of TGE on March 15, 1995 in its $102^{\text {nd }}$ Regular Session is not changed or repealed, refusing to enforce it is contrary to the principle of rule of law. It recalled that the previous five rounds of election were conducted not without a legal foundation but based on such decision of the Council of Representatives of the TGE and the Harari Regional State Constitution. (para 9).

\subsection{Issues addressed in the decision of the FSC Cassation Division}

FSC Cassation Division ordered the production of the Minutes of meeting of the Council of Representatives of the Transitional Government of Ethiopia made on March 15, 1995 in its $102^{\text {nd }}$ Regular Session, and election directives of the Harari state. (para 10). FSC Cassation Division addressed two issues - whether the Federal Supreme Court has jurisdiction to hear 
such case, and the constitutionality of those rules and practices which are relied upon. (par 11).

\subsection{Applicable rules}

The Cassation Court invoked the following rules in its disposition of the case:

- FDRE Constitution, articles 5(1), 9(2), 39(2), 50(3), 91(1) and (2);

- Courts Proclamation No 25/1995, article 3(1);

- Federal Courts Proclamation No 1234/2021, article 3(1)(a), (2);

- The Revised Harari State Constitution, article 50(2);

- The National Election Board of Ethiopia Establishment Proclamation No 1133/2019, article 17;

- The Ethiopian Electoral, Political Parties Registration and Election's Code of Conduct Proclamation No 1162, articles 17, 155(4);

- Consolidation of the House of Federation and Definition of its Powers and Responsibilities Proclamation No 251/2001, article 9;

- The Council of Constitutional Inquiry Proclamation No 798/2013, articles 3(2)(a) and 4(1);

- Minutes of the Transitional Government of Ethiopia Council of Representatives, $102^{\text {nd }}$ Regular Session, March 1, 1993.

- International Covenant on Civil and Political Rights, articles 1, and 27 ;

- International Covenant on Economic Social and Cultural Rights; and

- United Nations General Assembly Declaration No 47/135, December 12/1992.

\subsection{Procedural matters}

The National Election Board of Ethiopia in its administrative decision refused to register ethnic-Hararis residing outside of the state to vote for their representatives for the Harari State Council. The Harari National Council petitioned the Federal Supreme Court to quash the decision of the Board. The Federal Supreme Court thus reversed the decision of the Board. The Board in turn petitioned the Federal Supreme Court Cassation Division alleging fundamental error of law.

\subsection{Judgment of the Cassation Court}

The Federal Supreme Court Cassation Division addressed the first issue on two levels. From the point of view of the electoral law, it held that because such decision of the Board relates to the electoral process, it falls under article 17(1) of NEBE Proclamation No 1133/2019. The final decision of the Board under such provision is subject to review by the Federal Supreme Court. (para 13). 
FSC Cassation Division also held that the federal courts have jurisdiction to review matters that may be resolved based on the Constitution. It invoked article 3(1) of the Federal Courts Proclamation No 25/1996, articles 3(1)(a) \& 3(3) of the Federal Courts Proclamation No 1234/2021, and article 9(2) of the FDRE Constitution, and held that because courts have the obligation to apply the Constitution, the argument that they cannot interpret the Constitution is not acceptable. (para 14).

On the other hand, where constitutional interpretation is required for the determination of the matter, the court may refer the matter to the Council of Constitutional Inquiry as per articles 3(2)(a) and 4(1) of the Council of Constitutional Inquiry Proc. No 798/2013. However, the determination of whether a particular dispute involves constitutional interpretation is the responsibility of the court. (para 15). The Cassation Division, thus, held that the Federal Supreme Court has jurisdiction to see this matter. (para 16).

Going to the merit of the case, FSC Cassation Division held that the Harari People State Council has two chambers -the State Council of Representatives to be elected by all residents of the state, and the Harari National Council to be elected only by ethnic-Hararis. Among the 36 members, 22 are members of the State Council of Representatives while 14 are members of Harari National Council. It can be observed that such arrangements were made based on the decision of the TGE Council of Representatives decision in its $102^{\text {nd }}$ Regular Session. The principal responsibility of the Harari National Council is maintaining the circumstances for the preservation of the Harari identity by preserving its language, culture, heritage and identity. The Cassation division asserted that it is with a view to achieve this objective that only ethnic-Hararis residing both inside and outside of their state would, thus, elect those 14 members. (para 18).

FSC Cassation Division indicated that the minutes of the decision of the TGE Council of Representatives would be applied even after the adoption of the FDRE Constitution, and that it was made based on the principles of the Constitution. It noted that this is the reason such arrangements are reflected in the state constitution, and that such decision is adopted after the coming into force of the FDRE Constitution whose basic principles it has taken into consideration. According the reasoning of the FSC Cassation Division, the federal Constitution under articles 5(1), 39(2), 91(1) and (2) affords protection to language, culture, heritage, and identity that are fundamental for the preservation of identity of nations, nationalities and peoples; It can also be observed that the FDRE Constitution affords special protection to ethnic groups with minority population. FSC Cassation Division further lists international instruments, such as ICCPR (articles 1 and 27), ICESCR, and 
UN General Assembly Declaration No 47/135 adopted on December 12/1992. The FSC Cassation Division held that the Harari State Council is, therefore, established in special form in order to promote such protection to the language, culture, heritage and the manifestation of identity of the Harari People which is constitutional. (para 19).

The FSC Cassation Division further held that the TGE Council Representatives decision on its $102^{\text {nd }}$ Regular session, and the provisions of the Harari Regional State Constitution are aligned with the claims of respondent. (para 20). It held that as provided for under article 9 of Consolidation of the House of Federation and Definition of its Powers and Responsibilities Proclamation No 251/2001, unless there is a contrary decision, a statute is deemed to be constitutional. It stated that the organ that is vested with interpretative power of the Constitution is provided for under article 4(1) of the CCI Proclamation No 798/2013, and FDRE Constitution article 62(1). Accordingly, the FSC Cassation Division decided that the Board's decision is unconstitutional and unacceptable because it disregards the decisions of the TGE Council of Representatives made in its $102^{\text {nd }}$ Regular Session allowing ethnic-Harari residing outside their state voting for the Harari National Council, as well as related provision of the Harari Regional State Constitution.

The FSC Cassation Division indicated that the decision of the TGE Council of Representatives and the provisions of the Regional State Constitution were not declared unconstitutional by any organ that has authority. Based on this premise it concluded that in so far as those decisions of the TGE Council of Representatives and the Regional State Constitution are not declared unconstitutional, they are presumed to be constitutional; and thus, the decision of the Federal Supreme Court is affirmed. (para 21).

\section{Critiques based on Electoral Principles}

\subsection{Universal and equal suffrage}

The right to participate in the affairs of the state, to run for a public office and to vote for one's representative is a right reserved for citizens only. ${ }^{3}$ In an electoral process for public office, representation is ensured by a

\footnotetext{
${ }^{3}$ Democratic rights are restricted to citizens. The Constitution is clear in its demarcation between human rights and democratic rights. Those rights that emanate from the nature of mankind are provided for under article 10(1) as "inviolable and inalienable". Sub-article (2) provides that "democratic rights of citizens and peoples shall be respected".
} 
universal and equal suffrage which is enshrined in article 38(1)(c) of the FDRE Constitution. ${ }^{4}$ Representation of citizens in public office is further ensured through the equality of votes, one-person one-vote principle, which is incorporated into the electoral law. ${ }^{5}$ As accurate equality of votes cannot be established; there could be difference in value of votes from one electoral constituency to another; however, such population deviation between two constituencies may not exceed $15 \%{ }^{6}$

Therefore, every Ethiopian that is not precluded from voting either by law or court order, is entitled to vote for candidates in his/her locality irrespective of ethnic identity. However, the issue that is presented before the FSC Cassation Division regarding voting for members of the Harari National Council is not whether it is constitutional that only ethnic-Harari should elect the 14 Harari National Council Members, but rather whether those ethnic-Harari residing outside of their state should be allowed to vote for Harari State Council members.

However, both issues should have been addressed by the Court. The world has come thus far to obtain universal and equal suffrage for citizens, that every person should be given the right to vote for his/her representative. That includes women and in some nations racial and other minority groups. It appears Ethiopia is maintaining ethnic majority-minority when such rules are maintained to preserve minorities because they are outnumbered in the constituency that is claimed to belong to a particular group.

\subsection{Powers of the Harari National Council}

Elections are always contentious because they are not only representations of the identity of the electorate but are also processes of exercising selfgovernance, as the elected officials are often lawmakers, making laws to be applied. FSC Cassation Division held that the principal responsibility of the Council is maintenance of the Harari identity. (para 18). The same statement is stated in the decisions of the TGE Council of Representatives, and the FSC did not expressly make reference to the contents of the power of the Council in the Harari Regional State Constitution. This gives an impression that FSC Cassation Division wanted to present the Council as apolitical. ${ }^{7}$

\footnotetext{
${ }^{4}$ Also see the Ethiopian Electoral, Political Parties Registration and Election's Code of Conduct Proclamation No 1162/2019 (“Electoral Proclamation No 1162/2019”), art 5.

5 Id. art 5(3).

${ }^{6} I d$. art 13(1)(b). Equality of votes is a serious constitutional issue. See for instance Case Numbers: 2003 (Gyo-Tsu) No. 15; 2003 (Gyo-Tsu) No. 24; 1998 (Gyo-Tsu) No. 28; and 2001 (Gyo-Tsu) No. 223 litigated before the Japanese Supreme Court.

${ }^{7}$ Minutes of the TGE Council of Representatives, para 3.2, first statement.
} 
The power of the Harari National Council members may be read from the provisions of the Harari Regional State Constitution. As already stated, the Harari People State Council has 36 members and is constituted of two chambers. ${ }^{8}$ The Harari State Peoples Representatives Council is composed of 22 members. Of those, 4 members are elected from Jogul (exclusively inhabited by Harari) and 18 are elected from outside of Jogul which also includes other ethnic groups. ${ }^{9}$ The Harari National Council members are 14 and they are exclusively elected by ethnic-Harari. ${ }^{10}$

The Harari People State Council is "the supreme political organ in the state". ${ }^{11}$ As such, it adopts and amends the state's Constitution and other laws; ${ }^{12}$ it exercises all powers granted to states by the FDRE Constitution; ${ }^{13}$ it approves the appointment of the regional president nominated by the Harari National Council $;{ }^{14}$ it approves the appointment of judges, land use policies, levies state taxes, determines the state's budget, declares state of emergency, etc. ${ }^{15}$ While the speaker of the Council is nominated by the Harari People State Council, the deputy speaker is nominated by the Harari National Council. ${ }^{16}$

These provisions show that the Harari National Council is the most important political organ in the State and it has few key exclusive powers. Therefore, excluding non-Harari ethnic members of the state from voting for the Harari National Council is discriminatory because it denies the majority the right to vote in election -representation and self-governance. Even though decisions in such lawmaking organs are passed by majority, in a Council with 36 members, having $18^{17}$ exclusive Harari members most certainly defines the outcome.

${ }^{8}$ The Revised Harari State Constitution, arts 48, 49, 51.

9 Id. arts 49 and 50.

${ }^{10}$ Id. art 50(2). These powers of the Harari National Council are also stated in the Minutes of $102^{\text {nd }}$ Regular Session of TGE Council of Representatives.

11 Id. art 51(1).

${ }^{12} I d$. art 51(2)(a)(b).

13 Id. art 51(2)(c).

14 Id. $\operatorname{art} 51(2)(\mathrm{d})$.

${ }^{15} I d$. art 51(2)(m).

16 Id. art 52(3).

${ }^{17}$ It is to be noted that of those 22 members of the Harari People State Council, 4 of them are to be elected from Jogul, exclusively Harari. 


\section{Critique based on the Territorial Nature of the Right to Vote}

Voting for representatives relate to both representation and self-governance. This is either territorial or based on identity. Although most regional states are named after the major ethnic group in the state, there is no state in the federation that is constituted of only one ethnic group. Therefore, all citizens that are residents in the electoral constituency of a regional state vote for their representatives. While the electoral system recognised in the Constitution is plurality of votes (first past take the post), the actual representation in the House gives the impression that there is a proportional representation. ${ }^{18}$

One of the principles that arises in this case is whether the right to vote is territorially limited. Although the right to vote is limited to citizens, this notion of citizens represents only national citizen, not a citizen of a regional state or ethnic group. The Constitution makes this clear by making reference to "Ethiopians". 19

This provision further limits such rights to those who attained age of 18 and the rest is left for the sub-constitutional law to be adopted by the Federal Government vested with the power to legislate "in order to give practical effect to political rights provided for in this Constitution, all necessary laws governing political parties and elections". ${ }^{20}$ To this end, "the House of Peoples' Representatives shall enact specific laws on [] matters [of]: ... enforcement of the political rights established by the Constitution and electoral laws and procedures". ${ }^{21}$

Elections necessitate organization; and one such organisation is election constituency based on the available census data. ${ }^{22}$ Eligible candidates' registration is conducted by such constituencies. ${ }^{23}$ The Board also establishes polling stations under such constituencies and announces such polling stations to the public. ${ }^{24}$ Such polling stations are where "voters'

18 The FDRE Const., art 54(2) provides that "[m]embers of the House shall be elected from candidates in each electoral district by a plurality of the votes cast."

${ }^{19}$ FDRE Const, art 38

20 Id. art 51(15)

${ }^{21}$ Id. art 55(2)

${ }^{22}$ Electoral Proclamation No 1162/2019, supra note 4, art 13(1)(a). This is an implementation of the principle of equality of votes.

${ }^{23}$ Id. art 14(1)(b).

${ }^{24}$ Id. art 15(1). 
registration, casting and counting of votes take place." 25 In this sense, constituency is residence of the voters, a place they live in and they have the intention to continue living; a community with which they share several layers of interests - social, political, economic, etc.

The electoral law, therefore, further requires that a person may be registered as a voter if he "has been residing within the constituency for at least 6 months." 26 The law further provides for the manner of establishing such residency requirements. ${ }^{27}$ There is no exception to this, even if there can be extension of it. Under article 17, the electoral law introduces establishment of special polling stations. Such special polling stations are established for those who are away from home because of their official assignments, such as members of the military living in camps, civil servants, or college students, and internally displaced people or those incarcerated and who still have their right to vote. These individuals are away from their habitual residence temporarily and they would be voting in their original constituency.

The candidate elected from that locality thus represents (the interests of) the place where he is elected. This is clearly based on the notion of selfgovernance. Election in Ethiopia is, therefore, territorial by its very nature. ${ }^{28}$

\section{Critique on the Interpretative Methods of the FSC Cassation Division}

\subsection{Taking the easy route}

The first ground for NEBE's petition submitted to the Cassation Court (against the decision of the Federal Supreme Court) raised issues of jurisdiction by indicating that the demands of the Harari state representatives and the provision of the Harari Regional State Constitution contradict with the FDRE Constitution. The petition stated that this calls for constitutional interpretation and such power is reserved for the House of Federation, and it argued that the Federal Supreme Court does not have jurisdiction to see the matter. The second issue addressed in the cassation petition is substantive and it relates to the decision of the TGE Council of Representatives and the provisions of the Harari state Constitution that are contrary to the

${ }^{25}$ Id. art 15(3), 16(1).

${ }^{26} I d$. art $18(1)(\mathrm{c})$.

${ }^{27}$ Id. art 21.

${ }^{28}$ One could argue whether the Ethiopian federalism is territorial or identity based. For the most part, it is not individual identity-based federalism. 
Constitution and, thus, unconstitutional. The Cassation Court seems to have taken the easier route because it avoided addressing both issues.

\subsection{The issue of jurisdiction}

The objection of the National Election Board of Ethiopia regarding jurisdiction of the Federal Supreme Court relates to the constitutional interpretation the matter demands. For an innocent reader, the Cassation Court appears to be reacting to its long standing criticism against the courts timidity in interpretation of the Constitution for the purpose of application. ${ }^{29}$ The Cassation Court even renders a dictum regarding jurisdiction. FSC Cassation Division held that because courts have the obligation to apply the Constitution, the Federal Supreme Court has jurisdiction to see matters involving the application of the Constitution. ${ }^{30}$ Where the matter requires constitutional interpretation the court may refer it to the House of Federation. However, whether the matter involves constitutional interpretation or not is a subject to be decided by the court. Yet, FSC Cassation Division did not address the issue whether this litigation involves constitutional interpretation.

\subsection{Constitutional interpretation}

Constitutional interpretation refers to two distinct subjects in Ethiopian jurisprudence. The first relates to the practice of giving content to the provisions of the Constitution for the purpose of application of such constitution. In its judgement (para 14) the FSC Cassation Division refers this as falling under the jurisdiction of the courts. The other meaning of constitutional interpretation refers to a condition wherein, for instance, a rule of a sub-constitutional norm or a decision of government official contradicts with the Constitution, and needs to be quashed. FSC Cassation Division decision (paragraph 15) refers to such type of constitutional interpretation as reserved to the House of the Federation. ${ }^{31}$ It is the second meaning of interpretation the parties were litigating in these cases.

29 Tsegaye Regassa (2000), "Courts and Human Rights Norms in Ethiopia: An Overview" in Proceeding of Symposium on the Role of Courts in the Enforcement of The Constitution (Ethiopian Civil Service College,) 113; Simeneh Kiros Assefa, Criminal Procedure Law: Principles, Rules and Practices (Xlibris 2010) $64 \mathrm{ff.}$

${ }^{30}$ Despite it invoked the provisions of both the Courts Proclamations, the decision is very much influenced by the provisions of Courts Proclamation No 1234/2021, art 6(1)(a) which provides that the Federal Courts shall apply on the basis of "the Constitution, Federal Laws and International Treaties to which Ethiopia is a party".

31 Yonatan Tesfaye Fesseha (2008) "Whose Power is It Anyways: The Courts and Constitutional Interpretation in Ethiopia" 22 J Eth L 128; Assefa Fiseha (2007), 


\subsection{Constitutionality of the disputed rules and practices}

Regarding the constitutionality of the decision of the TGE Council of Representatives and the Harari Regional State Constitution and the practices of five rounds of election, FSC Cassation Division brushed this issue away by presumption that rules are deemed constitutional unless they are reversed. FSC Cassation Division, invoking article 9(1) of the HoF Proclamation ${ }^{32}$ held that while a certain statute's constitutionality is under review "unless proved to the contrary [it] is presumed to be constitutional". Based on such rule, FSC Cassation Division held that the May 1995 decision of the Council of Representatives of the Transitional Government of Ethiopia on its $102^{\text {nd }}$ meeting -that the Harari National Council may be elected by out of state Harari 'residents'- as well as the provisions of the regional state constitution are deemed constitutional until such time they are invalidated by a body that has power to do so. (para 21).

This assumption is partly wrong. First, article 9(1) of the HoF Proclamation deals with already existing or promulgated 'law', not any parliamentary decision. However, FSC Cassation Division has reviewed the Minutes of the $102^{\text {nd }}$ Regular Session of the TGE Council of Representatives and not a law enacted by the parliament. ${ }^{33}$ The review of the Minutes of TGE Council of Representatives makes it evident that it did not come out in statute form; therefore, it is not law that vests rights and imposes obligations under state sanction. This is even clearer from the reading of the provision of article 71(2) of the Constitution which requires the president of the republic to proclaim laws adopted by the lawmaker in the Negarit Gazeta. ${ }^{34}$

On the other hand, the decision of the National Election Board of Ethiopia is based on duly promulgated law. This argument is inseparably connected to the second wrong assertion of FSC Cassation Division. Under para 19, it holds that "it can be gathered from the Minutes of the Council of Representatives of the Transitional Government in its $102^{\text {nd }}$ Regular Session

"Constitutional Adjudication in Ethiopia: Exploring the Experience of the House of Federation (HOF)", 1 Mizan LR 1; Gedion Timothewos (2010), "Freedom of Expression in Ethiopia: The Jurisprudential Dearth" 4 Mizan LR 2: 201; Getachew Assefa (2010), "All About Words: Discovering the Intention of Makers of the Ethiopian Constitution on the Scope and Meaning of Constitutional Interpretation" 24 J Eth L 139.

${ }^{32}$ Consolidation of the House of the Federation and Decision of its Powers and

Responsibilities Proclamation No 251/2001.

33 The Judgment, para 10.

${ }^{34}$ For further reading of the publication of laws read Federal Negarit Gazeta Establishment Proclamation No 3/1995. 
that it would be applied even after the coming into force of the FDRE Constitution and it was decided in conformity with the principles of the Constitution." The minutes nowhere state the temporal application of such decision. Further, it never states whether the decision takes into consideration the principles of the newly adopted constitution nor does it state any particular principle.

Yet, where such presumption is challenged by the parties, FSC Cassation Division should either affirmatively address the issue that such rules and practices are constitutional if it believes the two do not contradict, or refer the matter to the House of Federation. FSC Cassation Division did not affirmatively state that those decisions, practices and rules are constitutional; nor did it refer the matter to the House of Federation for constitutional interpretation.

\subsection{Was there a need for constitutional interpretation?}

It is argued by the NEBE before the Cassation Court that the power to make electoral laws is granted to the Federal Government. Therefore, states do not have the power to make electoral laws other than defining the number of seats. The review of Electoral Proclamation No 1162/2019 shows that voters' registration is governed by this statute. Therefore, a voter needs to be Ethiopian national, who has been residing for the past 6 months in the locality he intends to cast his vote, is not disqualified by law or court order, and is able to produce evidence of his identity.

Article 51(15) of the FDRE Constitution provides that the House of Peoples Representatives has the power to adopt electoral laws and rules that regulate political parties. And according to article 50(5), state councils have the power to legislate on matters that are reserved for states. It further provides that the state councils have "power to draft, adopt and amend the state constitution" the content of which is consistent with the provisions of the Federal Constitution.

Article 50(3) also provides that the state council is "the highest organ of state authority" and it is "accountable to the people of the state." The provision is clear that the accountability of the state council is to every member of the regional state, not to a particular ethnic group. Even if the decisions of the TGE Council of Representatives were to be considered as rules, they are repealed by article 162(2) of the Electoral Proclamation No $1162 / 2019$ which provides that "[a]ny law which contradicts this Proclamation shall not be applicable on matters covered by this Proclamation." However, it is not clear whether a conflict between the provisions of a regional state constitution and laws adopted by the Federal Government would call for constitutional interpretation. 


\section{Critique based on Judicial Practice}

\subsection{Improper reading of the relevant provisions on the dispute}

It goes without saying that where parties are disputing, the contents of a legal rule, the court would read such provision carefully. In the present case, the FSC Cassation Division does not appear to have carefully examined article 50(2) of the Revised Harari State Constitution, which is verbatim copy of article 25(2) of the replaced state constitution. ${ }^{35}$

Paragraph 3 of the Judgment of the Federal Supreme Court Cassation Decision states that the NEBE refused registration of ethnic-Hararis residing outside of the state to vote for their representatives contrary to what is provided for under article 50(2) of the State Constitution. The Board's argument is that the provisions of article 50(2) of the Harari Constitution contradict with the provision of article 50(3) of the FDRE Constitution.

It is to be noted that the claim of voting rights based on ethnicity irrespective of place of residence is not in tandem with the objectives envisaged under article 17(3) of the Electoral Proclamation No 1162/2019 that deals with special procedure to be submitted by the Electoral Board to HoPR in order "to enfranchise citizens residing abroad or for those who cannot vote in their residence for other reasons". This provision can only accommodate residents of a constituency (irrespective of ethnicity) who are temporarily outside their place of primary residence during elections.

The Cassation Court when addressing the issue of constitutionality of those decisions and rules, did not dwell on what they provide for. However, the FSC Cassation Division states that during the preceding five rounds of elections, Harari National Council members were elected by those ethnicHarari residing both within and outside of the state. (para 17). It further states that the votes of such ethnic-Harari voters would involve in voting only those 14 members in the Harari National Council. (para 18).

But careful reading of the Amharic version of article 50(2) of the Harari State Constitution gives a different meaning than the one that is litigated before FSC Cassation Division. Sub-article 1 provides that the Harari People State Council is constituted of members elected from two constituencies.

35 The Harari state uses Amharic as its working language but the legally sanctioned working language of the State are Harari and Oromigna. The Constitution was published in the three languages and it provides that where there is a difference between the Harari and Oromigna language, the Amharic version shall prevail. (Art 80 ). This has also been the case under article 42 of the first Constitution adopted on September 11, 1995. 
Under (a) it is provided that 4 members are elected from Jugol constituency, and under (b) it is provided that from the constituency including urban and rural kebeles outside of Jugol 18 members are elected. In similar manner sub-article (2) provides that the Harari National Council members may be elected from among members of Harari nationality residing both within the state and outside of the regional state (i.e. in other regional states and cities). This contested provision governs candidates, not electorates.

In this sense, it is rather consistent with the electoral law -Proclamation No 1162/2019, article art 31(1)(c)- that individuals may run for office in their birthplace without the requirement of the 6 months residency requirement. However, such person, once elected, is required to reside in that place of his candidature.

The Cassation Court appears to have been misled by what is provided for under paragraph 2.1.2.2, first statement of $102^{\text {nd }}$ Regular Sessions of the minutes of the TGE Council of Representatives. If the Cassation Division is so deceived by the paragraphs in the decision of the TGE Council Representatives, it is presumed it did not carefully examine the report in its entirety.

\subsection{Failure to address issues directly}

There are binding interpretative decisions of the Cassation Court that require a court to give direct and explicit ruling on matters that are pleaded by the parties. ${ }^{36}$ Further, it is the practice of the profession that in writing judgment, the court first summarises the written pleadings and oral arguments of the parties. Such facts are selected based on their relevance for the determination of the issue at hand. It is based on such pleadings and hearing of the parties the Court frames the issue to be resolved. ${ }^{37}$

Once the court has made such summary of facts, it is supposed to address such facts as stated in its summary. There are two fundamental allegations FSC Cassation Division did not address. First, the NEBE alleges that the provisions, the practices, and the decision contradict the Constitution. In ideal situation, FSC Cassation Division would make a direct ruling whether those practices, decisions and rules would contradict the Constitution.

FSC Cassation Division held that the Federal Supreme Court has jurisdiction to see matters that involve the Constitution for their disposition.

\footnotetext{
${ }^{36}$ Leulseged Bonne v Ethio-Leather Industry PLC (April 2, 2009, Cass File No 39144, in 8 Decisions of the Federal Supreme Court Cassation Division).

${ }^{37}$ Midrock Construction PLC v Solomon Abebe (January 29, 2009, Cass File No 37105 in 8 Decisions of the Federal Supreme Court Cassation Division).
} 
Where the matter requires constitutional interpretation, the court may refer the matter to the House of Federation. However, whether the matter involves constitutional interpretation or not is a subject to be decided by the court. However, FSC Cassation Division did not address the pleadings of the NEBE that those practices and decisions contradict the Constitution. FSC Cassation Division held that legal rules are presumed constitutional unless they are reversed by an organ that has jurisdiction. The decision of the FSC Cassation Division does not affirmatively state that those decisions, practices and rules are constitutional.

Looking at it from another perspective, FSC Cassation Division did not address another allegation by the Harari National Council. The Harari National Council alleged in its response that the Harari State Constitution does not contradict the FDRE Constitution. It also argued that the decision of the TGE Council of Representatives in its $102^{\text {nd }}$ Regular Session and the Harari State Constitution are positive actions towards the recognition and enforcement of the rights of the Harari people, and are thus in conformity with the FDRE Constitution. The arguments of the Harari National Council further included that such rights of minorities are recognised in international instruments to which Ethiopia is a party and which should be complied with in the voting procedure the NEBE. FSC Cassation Division has failed to directly examine and address these issues.

\subsection{Allowing wrong impressions to stand}

The Harari National Council randomly cited provisions and legal documents without a proper analysis of the content of those provisions, which is maintained by FSC Cassation Division. (paras 9, 19). FSC Cassation Division cited the provision of article 5(1) of the Constitution which recognises all languages as equal, but it stated that "the Constitution under articles 5(1), 39(2), 91(1) and (2), affords protection enabling the growth and maintenance of language, culture, heritage and identity of nations, nationalities and people" and it noted its observations that "the Constitution protects manifestations of identity language, culture and heritage from extinction of those groups because of their minority in number". FSC Cassation Division further lists international instruments, such as ICCPR (articles 1 and 27), ICESCR, and UN General Assembly Declaration No 47/135 adopted on December 12/1992.

In fact, there are constitutional provisions that are meant for the protection of the rights of minorities to be represented in parliament, as discussed in Section 7 below. However the FSC Cassation Division did not analyse how those provisions are harmonised with the various constitutional provisions with a view to ensuring the representation of minority ethnic 
groups. The issue whether those provisions allow out of state members of the group vote for representatives of such state is not expressly addressed. The actual effect of the demands of Harari National Council and the decisions of the TGE Council of Representatives is discriminatory against those considered 'others' who reside in the regional state. Thus, they give the wrong impression that the claim by the Harari National Council stands valid, even though such blessing is not expressly given by FSC Cassation Division.

\subsection{Allowing misrepresentations (regarding public consultation) to stand unaddressed}

The Harari National Council representative stated several unfounded facts, one of which is discussed here. As respondent in the FSC Cassation Division proceedings, the Harari National Council stated that the Committee of Experts report (submitted to TGE Council of Representatives) had been drawn, among others, after a field visit, several rounds of consultation with and obtaining the consent of all the people in the state. However, the socalled consultation was made in order to demarcate the territory of the Harari state as including Hunde Woreda which was not based on referendum. There is no record that shows any other public consultation regarding electoral process and distribution of political power in the regional state. The records rather show that an important section of society had actually been vilified. $^{38}$

The FSC Cassation Division did not make any ruling. This may be excusable because it does not state it in the summary of facts. However, it is a common practice that parties are prohibited, both in their written pleadings and oral hearings, from stating facts that are not supported by evidence.

\subsection{The significance of minutes of TGE Council of Representatives}

\subsubsection{The core objectives of reference to legislative intent}

In the normal course of things, parliamentary debates are made with a view to make law; and in some instances, as part of the supervisory responsibility of the law-maker, to give instructions to the executive. Courts may, when necessary, look into these parliamentary minutes to examine the intention of

38 This has also been reported in the newspapers that a particular group had been constantly warned not to claim right. Such statements were made by Harari, ONLF, OLF and IFLO representatives. ENA Harari "There should be combat against those in pursuit of self-interest" Addis Zemen, Addis Ababa, September 23, 1991 (in Amharic) at 1, 7. ENA Dire Dawa "Those who strive to create inter-ethnic conflict should be confronted" Addis Zemen, Addis Ababa September 24, 1991 (in Amharic). 
the lawmaker. ${ }^{39}$ However, when the courts look into the minutes of parliamentary debates, it is with a view to understand what transpired at such discussion with a view to interpret a legal rule, the subject of a dispute before the court, and to determine the content of such rule based on the intention of the lawmaker. In the absence of an adopted rule that is to be interpreted by a court of law, there was no need to review the content of the decision of the TGE Council of Representatives.

\subsubsection{FSC Cassation Division's failure to consider the document in its entirety}

Where the FSC Cassation Division orders the production of the document, as it did in this case, ${ }^{40}$ it should review the document in its entirety because parliamentary decisions are always made based on background study of the problem, proposals based on such study and parliamentary debates. The Harari National Council representative presented only the part (6 pages) of the TGE Council of Representatives decision, which states the decision.

Review of the records of the TGE Council of Representatives show that the decision was not made just in one round of parliamentary debate. The discussion begun much earlier, but the first decision was made in the $36^{\text {th }}$ Regular Session of the TGE Council of Representatives on March 1, 1993. There were background studies presented to the parliament on which the decision is based.

The Minutes of the $102^{\text {nd }}$ Regular Session of TGE Council of Representatives contains fundamental background documents for the demarcation of would be state of Harari, the then Region 13. It includes minutes of meetings (conducted on October 6, 1992) by Hunde Woreda 85 Oromo representatives and 85 Harari representatives led by 6 discussants three from Harari National League and three from Oromo Peoples Democratic Organisation ('OPDO'). It was said to be decided that Hunde Woreda be included into the Harari state. The minutes are signed by the six

${ }^{39}$ The minutes of parliamentary hearings are the vantage points from which we see how the lawmaker decided. However, it is not without a problem. We see the vantage point of only those who speak in the parliament. A Daniel Oliver-Lalana 'Rational Lawmaking and Legislative Reasoning in Parliamentary Debates' in Luc J Wintgens and A Daniel Oliver-Lalana (eds), The Rationality and Justification of Legislation (Springer 2013) 136-38.

${ }^{40}$ The author contacted the HoPR Library Head and asked the content of the document that was sent to the court; he is told, it is the entirety of the document that was sent to the Court. 
discussants and the decision was made by a show of hands of those who participated at the meeting.

The matter was presented to TGE Council of Representatives through the then Election Commission on November 3, 1992. The letter states that the Election Commission reviewed and supported the Harari Experts' Report. The Report is about the election matters in Region 13 administration. It states in great length that the Harari people suffered extermination, exile and oppression under Menelik $\mathrm{II}^{41}$ and subsequent military and "neftegna" regimes.

The report presents that because of such oppressions, the Harari population is significantly reduced in contrast to what the report referred to as 'neftegna settlers'. ${ }^{42}$ The report further illustrates that the city of Harar was divided into three keftegnas; the Harari people reside within Jugol which is only one kefitegna, and the 'neftegna settlers' are outside Jugol in the other two kefitegnas, which were residences of civil servants, former police and army members. ${ }^{43}$ According to the report, the neftegna have large population that would diminish the identity of the Harari people; and under such circumstances, the Harari people would not have a chance to vote or be elected from those two keftegnas. Therefore, three solutions were proposed by the Experts.

The first proposal of the report was that in order to maintain the identity of the Harari state, legal protection to the majority seat of the ethnic-Harari in the state council should be put in place. ${ }^{44}$ This is done through the second and third proposals which were meant to limit the effects of the votes of the 'neftegna' or 'the settlers' and to increase the value of the votes of the ethnic-Harari. ${ }^{45}$

${ }^{41}$ The report principally mentions the battle at Chelenqo where several Harari family men died. The letter written by Emperor Menelik II is also annexed to the report.

${ }^{42}$ For illustrative purposes, the report includes list of state employees, see annex 2. Of the 3,952 employees, only 88 were Harari, 387 were Oromo, 937 were others, and the rest were Amhara. There are reports of summary dismissal of non-Harari. Human Rights Council 12 $2^{\text {th }}$ Report Compilation published in November 1997, at $39-40$.

${ }^{43}$ It should be noted that the most prestigious military officers academy, Harar Military Academy, was in the city of Harar.

44 See section 6(c).

${ }^{45}$ This is probably the first time the lawmaker used the word "settler" is officially recognised. 
The second proposal was introducing gerrymandering. ${ }^{46}$ Gerrymandering is the process of designing an electoral district in a manner favouring a particular group. This is effective in first past take the post electoral system which Ethiopia has adopted in the Constitution. In proportional representation, the effect of gerrymandering can be limited. Therefore, the electoral district was redesigned in a manner that favours the ethnic-Harari people. Harar Jugol has five gates; electoral districts were designed to follow those five gates from each of which 10 members were to be elected, totalling 50 members. This districting gives effect to the residents of Jugol and nullifies the votes of those two keftegnas resident outside of Jugol. ${ }^{47}$

The third method proposed was defining the 'neftegna' as 'settlers' (not as 'people') and the ethnic-Harari as 'residents' ${ }^{48}$ wherever they are, however long they have been away from the state of Harari. ${ }^{49}$ Thus, those ethnic-Harari may elect in Harari election as 'their constituency'. ${ }^{50}$

Designing electoral districts in a manner that gives one group an unfair advantage over another and legally guaranteeing unjustified majority of representation of a minority group against other groups (which admittedly are majority in proportion) is contrary to the constitutional principle of equality of votes. The decision of the TGE Council of Representatives is made to fully implement such proposals. If FSC Cassation Division had reviewed the document brought from the Parliament library, these are the matters FSC Cassation Division would have discovered and analyzed. This certainly demands constitutional interpretation (in the meaning FSC Cassation Division held) and thus falls under the jurisdiction of the House of Federation.

The six-page decision of the TGE Council of representatives is the last part of the compilation in the document, and FSC Cassation Division has not given due attention to other related documents which constituted grounds of the decision. The logical end of the decision of FSC Cassation Division is that it justifies discriminatory practices, including gerrymandering, to the extent of giving it a constitutional ground it does not have.

${ }^{46}$ See section 7.1 and 7.2. of the report of the experts. The word gerrymandering is used several times.

47 The special zoning of the electoral district is attached to the report, annex 3 .

${ }^{48}$ The intended word was 'indigenous' but it is not made clear. However, for election purposes the requirement is residence, the author chose to translate the Amharic "newari" as resident.

${ }^{49}$ See section 7.3 of the report.

${ }^{50}$ It should be noted that these provisions precede the provisions of the Gambella, and Benishangul-Gumuz state constitutions which define owners of the respective states. 


\section{Matters not Seen by the Court and Special Representation of Minorities}

\subsection{Matters not seen by the court}

It is evident from the reading of the reports of the Experts who reported for the creation of the Harari state that the population of the ethnic-Harari are minority in the state and the whole exercise is to grant majority seat in the state council and legally maintain such seat irrespective of both the current and future states of affairs. At least by the time the Harari state was established, such action created a majority-minority in the state electoral process. In simple terms, it created second-class citizens by diminishing the value of votes of non-Harari ethnic groups. FSC Cassation Division never considered any fundamental principles in resolving this dispute. FSC Cassation Division does not seem to care for the circumstances the NEBE found itself in.

\subsection{Special representation of minorities}

The right to vote is limited to citizens. The world has come so far to obtain universal and equal suffrage. To this end, every person should be able to exercise his right to vote for representatives. That includes women and, in some nations, racial and other minority groups. It appears that Ethiopia is maintaining ethnic majority-minority when such rules are maintained to preserve minorities because they are outnumbered in their constituency.

The notion of self-governance limits such rights only in few practical manners. First, a person should be within a majority-age threshold to vote, such age of majority being 18 . This is still discrimination, yet it is justified. There is also a residency requirement that a person should reside in a constituency where he is voting for his candidate which is a manifestation of self-governance. The person should reasonably be believed to continue residing in that constituency in order to be justified to vote for his representative. Otherwise, one would be electing representatives for others, not for himself.

That said, once a person is registered to vote, his vote has equal value with other voters -the principle of one-person one-vote. However, in some instances, there is an effort to bolster the votes of minority groups by special rules to afford them representation. Thus, article 54(2) of the FDRE Constitution provides that "...provisions shall be made by law for special representation for minority Nationalities and Peoples." Article 54(3) further provides that the House may have a maximum of 550 seats, of which "minority Nationalists and Peoples shall have at least 20 seats. Particulars shall be determined by law." 
It is based on such protection or promotion of the rights of minorities that the TGE Council of Representatives reserves one seat in the House of Peoples Representatives to the Harari State taking it as one constituency. Further, the Harari people taken as a minority nationality have one representative. The State also has one representative in the House of Federation. ${ }^{51}$ This, however, should not be read to diminish the value of votes of other ethnic groups residing in the state.

\section{Issues for the Future}

One may not claim that Ethiopia has both the culture and the institutions for constitutional litigation. It does not mean that the House of Federation and the Council of Constitutional Inquiry do not exist. It only means, they are political institutions which do not have even the procedures of leading such litigation. At least, there is no oral hearing of parties in the cases decided so far. It is only paper pleadings, and only in some politically (not legally) important cases.

This judgment of the Federal Supreme Court raises several questions rather than answering one. FSC Cassation Division held that it has the obligation to apply the Constitution in disputes where it deems is relevant. In such disputes involving important constitutional matters, such as the right to vote and self-governance, FSC Cassation Division needs to address several subjects. Only three of them are mentioned here as relating to the case at hand.

\subsection{The issue of 'ownership' of a region}

The FDRE Constitution recognises that every "Ethiopian [] has the right to liberty of movement and freedom to choose his residence." This right comes along with other fundamental human and democratic rights, including the right to vote, "to engage freely in economic activity and to pursue a livelihood of his choice anywhere within the national territory" to establish a family, etc. ${ }^{52}$

The background document in establishing the Harari State (i.e. the report of the experts) states its concerns. The population of the ethnic-Harari is outnumbered by others. The report justifies this by the battle against Emperor Menelik II and subsequent oppressive regimes. It is for this reason that the group demanded special protection. In such quest for special

\footnotetext{
${ }^{51}$ Minutes $102^{\text {nd }}$ Regular Session of the TGE Council of Representatives, Para 1.1.1. and 1.1.2., Para 1.2.1.

${ }^{52}$ FDRE Constitution, art 32(1), 38, 41(1), 34(1), respectively.
} 
protection of the group, the experts proposed that others, the report refers to as 'neftegna' be defined as 'settlers', and ethnic Harari to be defined as 'residents'.

The background documents of the Harari state is explicit in denigrating a particular group. There are also other regional state constitutions that implicitly give the impression that only the nationals of that regional state are entitled to certain rights to the exclusion of groups they consider 'others'. This is manifested by the fact that the constitutions of such regional states are considered as pacts among those groups in whose name the state is called. For instance, the Revised Benishangul-Gumuz National Regional Constitution, makes reference to "we the people of Berta, Gumuz, Shinasha, Mao and Komo nationalities". ${ }^{53}$ Further, article 2 provides that "...the owners of the state are Berta, Gumuz, Shinasha, Mao and Komo nation, nationalities." Likewise, the Revised Gambela Peoples National Regional Constitution refers "We the people of Agnewa, Nuer, Mezgenger, Oppo and Komo nationalities." 54

In terms of legislative documents, it appears to have started in the process of adoption of the National/Regional Self-Government Establishment Proclamation No 7/1992 which is taken to be the foundation of the FDRE Constitution in some respects. ${ }^{55}$ However, FSC Cassation Division had a chance to address an obvious question: what is the fate of those who reside in those states? What is the extent of the privilege to be "owner" of a state?

\subsection{The question of identity}

FSC Cassation Division resolved this case based on the protection afforded to a particular group. The most important question it did not address is: what is the theory of identity it has adopted? There are at least two theories of identity - the primordial theory and the social construct theory. What is the fate of those who are treated as 'others' if they speak the language of the ethnic group referred to as 'owner' of the state? what if that group also practices and professes the dominant culture in the state? How is this seen along with the national identity?

\subsection{Nature of constitutional litigation/ interested parties}

The parties in this case are only two - the National Election Board of Ethiopia and the Harari National Council. The impression FSC Cassation

${ }^{53}$ Id. Preamble, para 4

${ }^{54} \mathrm{Id}$. Preamble, para 3.

${ }^{55}$ Art 3 provides for the national self-government established then, in a manner giving impression of "owners" of the respective states. 
Division wants to give in this case is the interest of the Harari people and obligation of the National Election Board of Ethiopia. However, the content of the litigation is that there has to be measures in the electoral process that bolster the votes of the Harari people, because of their minority number, to keep their representation in order to maintain their "language, culture, heritage, and identity." However, it is also denying others those same rights. This is established both by the reports of the experts and the decision of the Cassation Court.

The overall content of the proposal of experts, whether by definition of identity or electoral districting, involves exclusion or diminution of the value of the votes of those non-Harari and bolsters the value of votes of Harari voters. This is discrimination based on national origin, based on language, and based on other prohibited factors of discrimination. This decision or action of the state is a threat to everyone that resides outside of his/her dominant state. Therefore, such matters should involve public interest litigation, and submission of amicus curie by those interested persons and groups.

\section{Conclusion}

Ethiopia is a mosaic of language, culture, religion, history and tradition. However, the undercurrent is alignment of various interests along those fault lines. In such cases, the law is the most important unifying factor towards civic allegiance and broader national identity where it is properly interpreted and applied. FSC Cassation Division is at the helm of such power addressing fundamental issues of division by remedying historical mistakes. Litigations relating to representation are better and peacefully resolved through the judiciary.

FSC Cassation Division could and would have achieved such ends by not plain reading of texts, where they are explicitly unfair to a particular group, but rather by applying fundamental constitutional principles. In the present case, the Federal Supreme Court Cassation Division has missed an important opportunity to address fundamental ills in the Ethiopian political system. It rather confined itself to its formal positivist approach of reading the plain texts, and at times avoiding issues that are sufficiently clear to be in want of addressing. 